\title{
Industrial development and evaluation of new protein sources: Micro-organisms
}

\author{
By D. A. Stringer, Imperial Chemical Industries PLC, Agricultural Division, \\ Billingham, Cleveland $T S_{23}$ I $L B$
}

\section{Introduction}

Animals normally eat the food provided by the environment in which they live. Intensive animal rearing practices have broken this pattern and animals now eat what is considered to be best by man, in both a nutritional and economic sense. Likewise, individual human populations have their own traditional dietary patterns which are dependent upon the availability of natural raw materials, imported products and the eating habits of the population.

Micro-organisms have played an important part in the development of dietary practices particularly for the human and, increasingly so, for the animal. Foodtreatment processes have evolved which utilize either the separated products of fermentation (e.g. beer) or, alternatively, a composite of fermented substrate together with the appropriate micro-organisms, which may be a yeast, fungus or bacterium (e.g. cheese and yogurt). Usually the quantity of micro-organisms present in the food is relatively small. During the last 50 years there has been an increasing tendency to use the cultivated micro-organism as a food source.

\section{Type of micro-organism}

Essentially four types of micro-organism have been developed-algae, bacteria, fungi and yeasts. Attempts to cultivate algae, specifically Scenedesmus, Spirulina and Chlorella, have naturally concentrated in those countries with abundant sunlight and suitable sources of fresh water. Bacteria have been the last type of micro-organism to be developed and the use of these as a nutrient is currently restricted to animal feeding. Fungi, e.g. Fusarium graminarium, have been exploited by Rank Hovis McDougall Ltd using waste starch as a substrate; this product has been evaluated satisfactorily for safety within the UK and is now being test-marketed for human application. Yeasts have been an accepted component of the human diet for a considerable period, and during both World Wars they were specifically cultivated and incorporated in the diet as protein and vitamin sources. Candida utilis grown on wood-pulp wastes or ethyl alcohol is a commonly used dietary ingredient in processed food, particularly in the USA.

\section{Type of substrate}

During the last three decades considerable development has taken place using, what would be considered, unconventional substrates for micro-organism fermentation. For the purpose of this paper 'industrial development' will be taken 
to be synonymous with unconventional substrates. First, there were the pioneering developments of Champagnat et al. (1963) who showed that yeasts would grow on heavy gas-oil. This process was developed originally by British Petroleum (BP) at Lavera as a means of refining their crude oil. The development of molecular distilation by the chemical industry led to this concept being still-born. Nevertheless, BP realized the potential value of the yeast (Candida tropicalis), cultivated on these then cheap substrates, as a potential nutrient source in what was then considered to be a protein-deficient world. Lipid extraction was an essential feature of the process to remove the potentially hazardous substances retained in the residual oil. The next development was the use of purified $n$-alkanes which formed the substrate for the Grangemouth process using Candida lipalytica. Two installations, each capable of producing $100000 \mathrm{t} / \mathrm{year}$ have been built in Italy by Italproteine $\mathrm{SpA}$ and Liquichemica SpA. For a variety of reasons these plants have not produced material on a commercial scale and the factories now form part of the Italian State Chemical Company, ENI. Plants using similar technology are reputed to exist and function within the USSR.

Hydrogen has been studied as a substrate using Alcaligenes eutrophus but work has been limited to a laboratory scale (Bowien \& Schlegel, r $98 \mathrm{I}$ ). The recirculation of gaseous mixtures, e.g. air and hydrogen, or air and methane, led to considerable explosion and engineering risks. For some time it has been widely accepted that methanol is an attractive substrate for single-cell protein (SCP) production with the advantages of high purity and water solubility. Several industrial organizations have developed processes for protein production (Table I), but of these only Imperial Chemical Industries PLC, using the methanol-obligate organism Methylophilus methylotrophus, produce a commercially available product, which is called 'PRUTEEN'.

Commercial development of any of these processes depends upon an interaction between substrate cost and availability, the carbon conversion to organic material within the cell, cell growth rates, and the capital cost of fermenter and supporting equipment. The substantial increase in the cost of hydrocarbon energy seen over the last decade in Western Europe has changed the original attractive economic situation for SCP manufacture to one where it is now a marginal proposition. Soya, the main price determinent for animal feeds, has not increased in price so dramatically, and, as the cost of SCP is more energy related, the many optimistic forecasts for the nascent SCP industry have not materialized and there are few companies remaining who continue to develop the technology.

\section{Safety of industrially produced protein}

The universally accepted concept that food or feed should be safe, coupled with the development that has taken place in toxicological science, led automatically to the concept of safety evaluation for industrially produced SCP. The gas-oil process carries the inherent risk of carcinogenicity resulting from contaminant benzpyrenes. This objection does not apply to purified alkanes. Nevertheless, there was 
Table I. Substrates and organisms used in the production of novel protein sources

\begin{tabular}{|c|c|c|c|c|}
\hline Substrate & Organism & Trade name & Company & $\begin{array}{l}\text { State of } \\
\text { development }\end{array}$ \\
\hline Wood pulp & Ascomycete & Pekilo & $\begin{array}{l}\text { Finnish } \\
\text { Paper Industry }\end{array}$ & $\begin{array}{l}\text { Small-scale } \\
\text { production }\end{array}$ \\
\hline Wastc starch & Fusarium graminarium & - & $\begin{array}{l}\text { Rank Hovis } \\
\text { McDougall }\end{array}$ & Market evaluatio \\
\hline \multirow[t]{2}{*}{ Sulphite liquor } & Torulopsis sp & $\begin{array}{l}\text { Torula } \\
\text { yeast }\end{array}$ & & $\begin{array}{l}\text { Small-scale } \\
\text { production }\end{array}$ \\
\hline & Candida $\mathrm{sp}$ & .- & & \\
\hline Hydrogen & Alcaligenes eutrophus & - & & Laboratory \\
\hline Methane & $\begin{array}{l}\text { Pseudomonas sp } \\
\text { Hyphomicrobium sp }\end{array}$ & - & Shell & $\begin{array}{l}\text { Project } \\
\quad \text { discontinued }\end{array}$ \\
\hline \multirow[t]{4}{*}{ Methanol } & $\begin{array}{l}\text { Methylophilus } \\
\text { methylotrophus }\end{array}$ & PRUTEEN & ICI PLC & $55000 \mathrm{t} /$ year \\
\hline & $\begin{array}{l}\text { Methylomonas } \\
\text { methanica }\end{array}$ & Norprotein & Norsk-hydro & $\begin{array}{l}\text { Project } \\
\quad \text { discontinued }\end{array}$ \\
\hline & Methylomonas clara & Probion & Hoechst & $\begin{array}{l}\text { rooo } t / \text { year } \\
\text { pilot plant }\end{array}$ \\
\hline & Pseudomonas sp & $\cdots-$ & Mitsubishi & $\begin{array}{l}\text { Project } \\
\quad \text { discontinued }\end{array}$ \\
\hline \multirow[t]{3}{*}{$n$-Alkane } & Candida lipolytica & Toprina & BP (Italprotein) & $\begin{array}{l}\text { roo o00 } \mathrm{t} / \text { year } \\
\text { factory closed }\end{array}$ \\
\hline & Candida maltosa & Liquipron & Liquichemica & $\begin{array}{l}\text { Ioo o0o } t / \text { year } \\
\text { factory closed }\end{array}$ \\
\hline & Candida $\mathrm{sp}$ & Roniprot & $\begin{array}{l}\text { Rumanian } \\
\text { Government }\end{array}$ & $50000 \mathrm{t} /$ year \\
\hline Gas-oil & Candida tropicalis & 'Toprina & $\begin{array}{l}\text { Soc. Francais } \\
\text { BP }\end{array}$ & $\begin{array}{l}\text { I } 5000 \mathrm{t} / \text { year } \\
\text { factory closed }\end{array}$ \\
\hline
\end{tabular}

a need to demonstrate the safety of both these processes. The publications of de Groot et al. (1970a, 1970b, 1971, 1975) show that this risk was not realized. Other industrial producers of SCP have also had to carry out similar work. This is a lengthy and costly process. The main components of the toxicological testing have been set out in the guidelines written by the Protein-Calorie Advisory Group of the United Nations (Anon, 1972, 1974a) which refer to the format for rodent and farm animal experimentation. For animal-feed applications, greater emphasis was placed upon the toxicological evaluation of the product using farm animals, rather than relying upon laboratory animal studies. In practice, the evidence required by the regulatory authorities has been a combination of both target and laboratory species toxicology. This led to more extensive evidence being required for farm animal application in comparison with that supplied for direct human application.

The toxicological work using laboratory animals fed PRU'TEEN is indicated in Table 2. In the majority of cases the maximum PRUTEEN incorporation rate within the diet was $300 \mathrm{~g} / \mathrm{kg}$. This dietary incorporation level provides $210 \mathrm{~g} / \mathrm{kg}$ 
Table 2. Comparison of Protein Advisory Group testing guidelines and work conducted with PRUTEEN

\begin{tabular}{|c|c|c|c|}
\hline $\begin{array}{c}\text { Nature of test } \\
\text { evalaution }\end{array}$ & $\begin{array}{l}\text { Animal feed } \\
\text { guidelines } \\
\text { (Anon, 1974a) }\end{array}$ & $\begin{array}{l}\text { Human food } \\
\text { guidelines } \\
\text { (Anon, 1972) }\end{array}$ & $\begin{array}{l}\text { PRUTEEN } \\
\text { studies }\end{array}$ \\
\hline \multicolumn{4}{|l|}{$\begin{array}{l}\text { In vivo lab. animal } \\
\text { toxicological tests } \\
\text { Rat }\end{array}$} \\
\hline Acute & - & + & + \\
\hline $90 \mathrm{~d}$ & + & + & + \\
\hline 2 years or longer & + & + & + \\
\hline Multigeneration & Optional & + & + \\
\hline Teratology & + & - & + \\
\hline \multicolumn{4}{|l|}{ Other studies } \\
\hline $\begin{array}{l}\text { Pathology } \\
\text { Haematology } \\
\text { Biochemistry } \\
\text { Live-weight gain } \\
\text { Feed intake }\end{array}$ & $\begin{array}{l}+ \\
+ \\
+ \\
+ \\
+\end{array}$ & $\begin{array}{l}+ \\
+ \\
+ \\
+ \\
+\end{array}$ & $\begin{array}{l}+ \\
+ \\
+ \\
+ \\
+\end{array}$ \\
\hline Test levels & $\begin{array}{c}\text { Control + } 3 \text { levels } \\
\text { (50\% of dietary } \\
\text { SCP to be max. } \\
\text { test level) }\end{array}$ & $\begin{array}{l}\text { Control }+2 \text { or } 3 \\
\text { levels } \\
\text { (50\% of dietary } \\
\text { SCP to be max. } \\
\text { test level) }\end{array}$ & $\begin{array}{c}\text { Control }+2 \text { or } 3 \\
\text { levels } \\
\text { (1 } 50 \% \text { of dietary } \\
\text { SCP) }\end{array}$ \\
\hline \multicolumn{4}{|l|}{ Dog } \\
\hline 3 Months duration & - & + & $\begin{array}{l}\text { Beagle, I year } \\
\text { Dalmation, } 90 \mathrm{~d}\end{array}$ \\
\hline Metabolic studies & - & + & Renal function only \\
\hline Mutagenicity & - & + & + \\
\hline
\end{tabular}

crude protein. In addition crude protein is provided by cereals so that the final dietary crude protein level is vastly in excess of requirements for the majority of the animals studied. There was a need to provide suitable controls, usually given diets which were casein-based to a similar crude protein level, to distinguish between those effects caused by protein or PRUTEEN. Intermediate PRUTEEN incorporation levels were also used. Thus we attempted to follow, as far as practicable, the generally accepted toxicological principle of using the likely incorporation level (say $50 \mathrm{~g} / \mathrm{kg}$ ) and multiples of this usage pattern. However, the concepts developed for feed-additive testing of $\times 1, \times 10, \times 100$ or even $\times 1000$ are obviously impracticable for nutritional reasons, so that the calculation of a harmful effect level is impossible for this, or indeed any other foodstuff, when no biological observations of any consequence are seen within the tests.

In addition to the main stream of toxicological testing, certain features were recognized as potential risk areas. These had to be assessed in conjunction with the toxicological tests and were shown to be of no importance. They included: 
(a) Pathogenicity of the process organism: One of the earliest perceived problems concerned the pathogenicity. Any organism used on an industrial scale must be shown to be non-pathogenic to avoid threatening both the environment and the public at large. Methylophilus methylotrophus is an aerobic, methanol-obligate organism, hence it does not come as a surprise to find that when the viable cell is injected intraperitoneally into mice, either in a normal or in a cortisonecompromised situation, it fails to thrive and become parasitic upon the host which demonstrates non-pathogenicity. This situation is not quite so clear cut for the yeasts, as certain strains of Candida tropicalis are considered to parasitize the cortisone-compromised mouse but without causing mortality, thus leading to a rather indecisive area for this species of yeast.

(b) Substrate residues: Methanol is almost instantaneously metabolized by the PRUTEEN organism. The substrate cannot be detected at $4 \mathrm{ppm}$ in the final product, that being the lower detection limit. Methanol, despite the fact that it has well-known toxic effects in primate species, can be found in many alcoholic beverages at levels of up to $300 \mathrm{ppm}$. Residual substrates are found within products grown upon $n$-alkanes. For both 'Troprina' and 'Liquipron' (see Table $\mathrm{I}$ ) this has created problems in the opinion of certain regulatory authorities despite the fact that alkanes are used as food additives.

(c) Odd-chain and cyclic fatty acids: Odd-chain fatty acids are major constituents of SCP grown from $n$-alkane substrates. Although they are widely present in nature (Lester, 1979), their high concentration in $n$-alkane SCP products focused attention upon them as a likely health hazard. Initially there was considerable speculation about the importance of these fatty acids, especially after the demonstration that their concentration in animal adipose tissue increased with dietary SCP concentration. To a large extent the perceived problem was largely diffused by the work of Bizzi et al. (1980), who showed that they were metabolized. The odd-chain fatty acids are not present in bacterial SCP; within PRUTEEN hexadecanoic and cis- 9 -hexadecenoic acids are the predominant fatty acids ( $85 \%$ of total fatty acids) and they exist in a wide range of common food components. The presence of Io-methylene hexadecanoic acid, which provides $3.5 \%$ of the fatty acid profile for PRUTEEN, has prompted questions. This compound accumulates in adipose tissue in scarcely detectable quantities within the perirenal fat $(0.15 \%$ of total fatty acids) of pigs fed $300 \mathrm{~g} / \mathrm{kg}$ PRUTEEN for 12 weeks. In subsequent experiments we showed that it is apparently labile and disappears once PRUTEEN feeding ceases. Metabolic studies, again in the pig, showed that the final excretory products were short-chain cyclopropane dicarboxylic acids of which the major metabolite was 3,4-methylene adipic acid. The same cyclopropane dicarboxylic acids are found in human urine (Lindstedt $\&$ Wahl, 1974) but the dietary sources which ultimately provide these unusual fatty acids are not known. It is tempting to speculate that the endogenous bacterial flora, or alternatively lactobacillic acid (cis- I I, I 2-methylene octadecanoic acid) or sterculic acid (9,10-methylene octadec- 9 -enoic acid), being components of dairy products or margarines (via cottonseed oil), are the likely starting points. 
(d) Nucleic acids: There was a clear need to investigate and understand the role played by the high level of nucleic acids found in SCP (10\% for yeast, $14 \%$ for bacteria). The clinician, in assessing risk to humans, is conversant with uricemia resulting from excess nucleic acid intake. Although uricemia has only been recorded in primates it was necessary to demonstrate in a satisfactory manner the absence of uricemia or uric acid deposition within the tissues and joints of other animals fed SCP. This was achieved.

(e) Process contaminants: Heavy metals, nitrosamines, polycyclic hydrocarbons and mycotoxins have all been suggested as potential harmful contaminants. Excess levels of the first three may cause relay toxicity to the human, but as the levels detected are either the same, or less than those seen in conventional foods, the risk is negligible. In the case of heavy metals the concentration is controlled by defining the purity of the chemical feed stock. Mycotoxins have not been detected.

Arising out of the vast array of toxicological tests with laboratory animals were two minor observations which are worthy of comment. First, nephrocalcinosis seen in rats was PRUTEEN-dependent. It is likely that this effect was due to the imbalance of calcium, phosphorus and magnesium as all have an effect upon controlling this frequently observed lesion (Forbes, 1963; Du Bruyn, 1966). Specific studies with weanling rats fed PRUTEEN showed the lesion to be established after $30 \mathrm{~d}$ feeding, and to be non-progressive over $90 \mathrm{~d}$. Using various clearance tests to evaluate kidney function, no differences could be detected between PRUTEEN and control groups indicating that the rat kidney had sufficient reserves to overcome any impairment. The other abnormality detected in experiments involving laboratory animals was a transient inability of dogs fed either 300 or $600 \mathrm{~g}$ PRUTEEN $/ \mathrm{kg}$ to rise from their hind legs. The situation arises within the first few days of feeding PRUTEEN and recovery occurs within $4^{8 \mathrm{~h}}$ of initial occurrence. The observation was not seen in any other species, no pathological or clinical observations made in the dog gave any explanation as to its aetiology which still remains unresolved. The amount of PRUTEEN consumed in this situation is considered to be excessive; the daily intake was either 75 or I $30 \mathrm{~g}$ protein, derived exclusively from PRUTEEN, compared with $5^{8} \mathrm{~g}$ protein/d for the control diet, prepared from mixed protein components.

The remaining features of the toxicological experiments made with rats revealed no feature of biological consequence. Reproductive performance was not affected by PRUTEEN feeding. Fertility was high, pre- and post-natal survival was consistent between casein and PRUTEEN diets, no teratological abnormalities were evident in the specific studies designed to examine foetal change. Spontaneous carcinoma rates were the same for both control and PRUTEEN-fed animals in a 2 year study. Within the limitations of current toxicological science, we conclude that PRUTEEN is a safe feed for animals.

A further feature which falls under the broad heading of safety is the topic of occupational health. Early samples of PRUTEEN, prepared using spray-drying techniques, were very light and powdery in appearance. Dust from this material 
caused clinical symptoms which were initially thought to be an SCP allergy. Subsequent medical investigations lasting 5 years showed this not to be the case, although activation of complement is thought to take place (Mayes, 1982). Changing the drying technique to flash-drying, which produces a granular material, and the addition of small quantities of soya-bean oil to suppress the remaining dust, conveys upon the product more acceptable handling characteristics.

\section{Efficacy of industrially produced protein}

An equal, if not greater effort, was required to demonstrate product efficacy in animal diets. Three approaches were followed for PRUTEEN: definition of nutrient digestibility and availability, a demonstration of the validity of these values in the formulation of practical animal diets, and simulation of the laboratory animal toxicological experiments using the target species.

Linear programming techniques, as practised by the animal feed formulation industry, show that the most critical cost-reactive nutrients within the diet are available energy and the two first limiting amino acids, methionine and lysine. Considerable effort was expended in examining these features; values were determined in our own laboratories but also in the appropriate leading centres situated throughout Europe. The overall criteria commonly used in dietary formulation for all major classes of livestock are summarized in Table 3. The effectiveness of PRUTEEN as a nutrient source has been clearly demonstrated in the diets of young pigs (Whittemore et al. 1976), growing pigs (Braude $\&$ Rhodes, 1977) and breeding pigs (Waterworth \& Heath, I98I). For poultry the importance of amino acid supplementation has been demonstrated in chicks and turkeys (D'Mello, 1979a,b), whilst Vogt et al. (1975) described performances of both broilers and laying hens fed both practical and high levels of PRUTEEN. The typical scatter shown in growth performance tests resulting from PRUTEEN use in broiler diets was described by Lloyd \& Stringer ( 1978 ).

In the production of PRUTEEN, living cells are drawn off from the fermenter at a concentration of about $30 \mathrm{~g} / \mathrm{l}$. It is necessary to remove supernatant water and dry the material. Early experiments showed that the dried, intact cells had poor digestibility giving much reduced chick growth relative to soya-bean meal. Rupturing the cells, either by mechanical or chemical and heat-shock techniques significantly increased chick growth. Thus cell rupture is an integral part of the process for the production of bacterial SCP. ICI uses an acid/heat-shock technique as this is the most cost-effective method. Subsequent neutralization is necessary as chick growth was depressed using material produced below $\mathrm{pH} 4$. Reneutralization was achieved with caustic soda rather than caustic potash, cost grounds again being the criteria defining the process. The net result was a material high in ash, containing $\mathrm{Na}, \mathrm{SO}_{4}$ and $\mathrm{PO}_{4}$ in abundance, with negligible proportions of $\mathrm{K}$ and $\mathrm{Ca}$. Initially this was considered to be acceptable, however, independent work by Yoshida (1977) and Talbot (1978) revealed the importance of potassium, despite the fact that the nutritional requirement for this mineral had apparently been met 
Table 3. PRUTEEN: Description of nutrient composition

\begin{tabular}{ll}
\multicolumn{2}{c}{ Energy values (MY/kg air-dried material) } \\
Gross energy** (calves) & $21 \cdot 25$ \\
Digestible energy (calves) & 19.55 \\
Gross energy* (pigs and poultry) & $20 \cdot 00$ \\
Metabolizable energy (poultry) & 15.05 \\
Digestible energy (pigs) & 17.4 \\
Net energy (pigs) & $10 \cdot 1$
\end{tabular}

\begin{tabular}{lrrr}
\multicolumn{2}{c}{ Apparent } & \multicolumn{2}{c}{ Availability coefficients } \\
\multicolumn{2}{c}{ digestibility coefficients } & Lysine & 0.93 \\
Crude protein & 0.93 & Phosphorus & I.00 \\
True protein & 0.93 & & \\
Fat & 0.93 & &
\end{tabular}

$\begin{array}{lcc}\text { Proximate analysis }(\mathrm{g} / \mathrm{kg}) & \text { Granules* } & \text { Powder** } \\ \text { Moisture } & 100 & 80 \\ \text { Crude protein } & 720 & 700 \\ \text { True protein } & 540 & 520 \\ \text { Fat } & 85 & 130 \\ \text { Fibre } & <10 & <10 \\ \text { Lysine } & 42 & 41 \\ \text { Methionine + cystine } & 20 & 19 \\ \text { Threonine } & 35 & 34\end{array}$

$\begin{array}{lclc} & \begin{array}{c}\text { Minerals and metals composition } \\ \text { g/kg air-dried } \\ \text { material }\end{array} & \\ \text { Phosphorus } & 22 & \text { Iron } & \mathrm{ppm} \\ \text { Calcium } & 12 & \text { Copper } & 150 \\ \text { Sodium } & 0.2 & \text { Zinc } & <30 \\ \text { Potassium } & 1.8 & \text { Selenium } & <50 \\ \text { Magnesium } & 2.2 & \text { Arsenic } & 0.4 \\ \text { Chlorine } & 0.3 & \text { Altimony } & 0.1 \\ & & \text { Cadmium } & 0.1 \\ & & \text { Lead } & 0.1 \\ & & \text { Mercury } & 0.05 \\ & & \text { Fluorine } & <.01 \\ & & & <10.0\end{array}$

- Refers to PRUTEEN--granules incorporating ro g soya-bean oil $/ \mathrm{kg}$.

- Refers to PRUTEEN-Powder incorporating $55 \mathrm{~g}$ soya-bean oil $/ \mathrm{kg}$.

when PRUTEEN was incorporated in the diet. The latter author showed that the $\mathrm{K}+\mathrm{Cl}: \mathrm{Na}$ value was important in preventing mortality apparently caused by visceral gout. Subsequently, calcium hydroxide has replaced caustic soda in the neutralization stage of the process which renders the product more acceptable from the viewpoint of mineral balance.

Selenium deficiency has also been shown to be important. Exudative diathesis was demonstrated in chicks fed PRUTEEN (and a large number of other SCPs) by 
Yoshida et al. (1977) which was corrected by the addition of selenium to the diet. Selenium is now added to the fermenter growth-nutrients, not for the growth of the micro-organism but to ensure it is uniformly distributed throughout the dried cell mass at levels to meet nutritional requirements.

Other peculiar observations included enlarged livers in some broilers and laying hens. Only a small percentage of the population was affected at high dietary PRUTEEN levels. Histological examination of the livers showed foci of degenerating and necrotic hepatocytes with varying degrees of white-cell infiltration. There were changes in the blood aspartate serum transaminase levels, and the presence of the abnormality would be predicted within individual animals by detecting $\alpha_{1}$-globulin (which is normally absent in chickens) and increases in the $\beta_{2}-$ and $\gamma$-globulin factions. Using these as indicators we demonstrated that the abnormality is of a temporary nature and that animals reverted to normal once the PRUTEEN challenge was removed. The cause of the liver abnormality has not been defined, but a process modification has been applied which involves the addition of hydrogen peroxide to the cell mass prior to drying and which yields a product that no longer produces the abnormality. It also largley overcomes the depression in growth rate at high inclusion levels originally described by Vogt et al. (1975). We have reason to believe that this feature, originally described by Owen \& Doak (1978), and which from our evidence is totally specific to chickens, is given by all gram-negative bacteria. The feeding of excessive quantities of dried poultry manure to broiler chicks produces a mild form of the same abnormality.

The nutritional role of nucleic acids has promoted considerable discussion. The crude protein content of PRUTEEN is about $70 \%$, incorporating nucleic acid at $14 \%$. Put another way, amino acid-N provides $71 \%$ and nucleic acid- $\mathrm{N} 19 \%$ of the total nitrogen content with the remainder being contributed by glucosamine and ethanolamine, both components of the cell wall. In contrast, fish-meal amino acid$\mathrm{N}$ contributes $82 \%$ of the total $\mathrm{N}$ despite the fact that the simple arithmetical sum of the amino acids in fish equals approximately the value of the crude protein. Thus, there were two factors to evaluate, namely the usefulness of nucleic acid as a nitrogen source, and the effectiveness of PRUTEEN relative to fish-meal, remembering that the $\mathrm{N}$ in the latter is not all amino-acid derived.

The urinary excretory patterns of fish-meal and PRUTEEN-fed pigs are different. Urea (81\%), ammonia $(\mathrm{r} 6.3 \%)$, allantoin ( $\mathrm{r} \%$ ) and uric acid $(0.4 \%)$ account for the majority of urinary $\mathrm{N}$ excretion in fish-meal-fed pigs. In contrast the values are $61 \%, 24.8 \%, 4.4 \%$ and $0.6 \%$ respectively for PRUTEEN-fed animals (D'Mello et al. 1976); there is a decrease in urea excretion with a concomitant increase in ammonia and allantoin representing the end-points of pyrimidine and purine catabolism. The other important feature to note is the low level of uric acid-N excreted. These results, when combined with other information (D. A. Stringer, unpublished results) showing that levels of blood uric acid remain constant whilst there is a marginal rise in allantoin excretion, indicate that nucleic acid is catabolized. How useful is the nitrogen from this nucleic acid? The digestibility experiment of D'Mello et al. (1976) indicates that nucleic acid-N may 
be retained, and in a subsequent paper from the same group (Whittemore et al. I 978) there was an indication that it was utilized by $\mathrm{N}$-deprived pigs. In a series of experiments using chicks, D'Mello (1979c) also demonstrated that certain nucleic acid bases could be utilized as $\mathrm{N}$ sources. The extent to which utilization occurs was not easy to demonstrate, but the results of this and the studies made with pigs would certainly lead to the conclusion that nucleic acid- $\mathrm{N}$ should not be totally discounted. Other components of nucleic acid also contribute to the nutrient pool; ribose provides energy, and as the total phosphorus is $100 \%$ available that contributed by the nucleic acid ( $33 \%$ of total) is clearly of importance.

\section{SCP for human consumption}

Since SCP has been shown to support excellent growth in young animals with no toxic effects to mammals, there is considerable interest in its use as a nutrient for man. The average diet of man in developed countries is adequately supplied with protein. It is possible that the so-called 'junk foods' consumed particularly by the affluent young section in these countries is protein-deficient but it cannot constitute a serious need. Nevertheless, the nutritional properties demonstrated by $\mathrm{SCP}$ are of great interest to the food industry especially when nutritional value can be combined with functional properties such as water and fat binding, emulsification and gelling. The reported experience of Amoco with torula yeast, Rank Hovis McDougall Ltd with Fusarium, and Hoechst using Methylomonas clara suggests that there are good prospects for developing SCP concentrates and isolates which could find a place in the food market.

There appear to be three constraints on the use of SCP as human food: the name, the presence of nucleic acid and unusual clinical symptoms resulting from the use of certain SCPs. There are no problems in describing yeast SCPs as dietary constituents since yeast protein is a terminology easily accepted by the consumer. SCP from fungal proteins also enjoys the fully descriptive term mycoprotein. However, there are substantial pyschological problems with the term bacteriological protein (Anon, $1974 b$ ) and to overcome these the term microprotein (being short for microbiological protein) is suggested.

Application of both yeast and bacterial micro-organisms in human nutrition is limited by the nucleic acid level. It is constrained to a daily intake of $4 \mathrm{~g} / \mathrm{d}$ of which no more than $2 \mathrm{~g} / \mathrm{d}$ should be from an SCP source (Anon, 1975). Subsequent processing to reduce the concentration of nucleic acid removes the constraint. Numerous techniques exist for this (Chen \& Peppler, 1978). Conventional foods also contain nucleic acid, e.g. meat contains $10 \mathrm{~g} / \mathrm{kg}$ and liver $45 \mathrm{~g} / \mathrm{kg}$. With this in mind it seems reasonable to propose a reduction of SCP nucleic acid levels to $30-40 \mathrm{~g} / \mathrm{kg}$. Thus even with a high daily intake of microprotein of $50 \mathrm{~g}$, the constraint suggested by the PAG (Anon, I 975) is met.

There is another feature which limits the use of SCP in humans, namely unusual clinical symptoms. Initial experiments using hydrogen-metabolizing bacteria given to human subjects showed nausea, vomiting and diarrhoea (NVD) in some 
individuals (Waslien et al. 1969). These investigations have been taken further by Scrimshaw and his co-workers in a whole series of experiments conducted at the MIT (Scrimshaw \& Dillon, 1979). In addition to the NVD symptoms they have also seen papular skin rashes (SR) most noticeably at the extremities of the limbs. The symptoms result from both yeast and microproteins which suggests a common component despite their very different structural composition. At present, however, the full nature of the reactions is not understood. Although it is called an allergic reaction there is no correlation between NVD or SR and the various immune states usually measured. There is evidence that the clinical reactions can be removed as part of the processing to extract the nucleic acid. At this stage in the development of SCP for human consumption it is imperative to feed the product directly to humans, under supervision, with the objective of defining the extent of clinical responses and of understanding the factors that influence them, with the ultimate aim of process control to remove the effects. It is interesting to note the study, recently published by Bender \& Matthews ( 1981 ), showing that in a population of 1000 individuals $33 \%$ avoided one or more foods, and that between I and $4 \%$ were allergic to a specific food source. One may presume that in our current and developing consumer-orientated society these aspects of food allergy will be discussed more frequently.

\section{Micro-organisms as food in the future}

The evidence of the last 25 years has shown the food industry to be resourceful and innovative. Certain micro-organisms have formed an integral part of human dietary practice for centuries and the last 50 years has witnessed the first tentative steps in the use of more of these raw materials as food. The necessary techniques and legislation have been established to ensure that food derived from unconventional sources and substrates are thoroughly tested for safety and efficacy. This has been accomplished for animal food. If SCPs are going to be used for human food the major hurdles to be cleared are not of nutritional value, nor of safety, but of the psychology of change.

\section{REFERENCES}

Anon (1972). Preclinical Testing of Novel Sources of Protein. PAG Guideline No. 6 (revised). New York: Protein-Calorie Advisory Group, United Nations.

Anon (1974a). Nutritional and Safety Aspects of Novel Protein Sources for Animal Feeding. PAG Guideline No. I 5 . New York: Protein-Calorie Advisory Group, United Nations.

Anon (1 974b). Food Standards Committee Report on Novel Protein Foods. London: HMSO.

Anon (1975). Clinical Evaluation and Acceptable Nucleic Acid Levels of Single-Cell Protein for Human Consumption, report of 5th PAG ad hoc working group. New York: Protein-Calorie Advisory Group, United Nations.

Bender, A. E. \& Matthews, D. R. (1981). Br. Y. Nutr. 46, 403.

Bizzi, A., Veneroni, E., Tacconi, K. T., Codegoni, A. M., Pagani, R., Cini, M. \& Garattini, S. (1980). Toxicol. Letters. 5, 227.

Bowien, B. \& Schlegel, H. G. (I98I). Ann. Rev. Microbiol. 35, 405.

Braude, R. \& Rhodes, D. N. (1977). Livestock. Prod. Sci. 4, 91.

Champagnat, A., Vernet, C., Laine, B. M. \& Filosa, J. (1963). Nature, Lond. 187, 4862. 
Chen, S. L. \& Peppler, H. J. (1978). In Developments in Industrial Microbiology, p. 79 [L. A. Understoffer, editor]. London: Soc. Ind. Microbiol.

de Groot, A. P., Dreef-van der Meuten, H. C., Til, M. P. \& Feron, V. J. (1975). Fd Cosmet. Toxicol. 13, 619.

de Groot, A. P., Til, M. P. \& Feron, V. J. (1970a). Fd Cosmet. Toxicol. 8, 267.

de Groot, A. P., Til, M. P. \& Feron, V. J. (1970b). Fd Cosmet. Toxicol. 8, 499.

de Groot, A. P., Til, M. P. \& Feron, V. J. (1971). Fd Cosmet. Toxicol. 9, 787.

D'Mello, J. P. F. (1979a). Anim. Feed Sci. Technol. 4, 63.

D'Mello, J. P. F. (1979b). Anim. Feed Sci. Technol. 4, 209.

D'Mello, J. P. F. (1979c). F. Sci., Food Agric. 30, 381 .

D'Mello, J. P. F., Peers, D. G. \& Whittemore, C. J. (1976). Br. F. Nutr. 36, 403 .

Du Bruyn, P. B. (1966). S. A. Med f. 40, 5 I4.

Forbes, R. (1963). F. Nutr. 80, 321 .

Lester, D. E. (1979). Prog. Fd Nutr. Sci. 3, I.

Lindstedt, S. G. \& Wahl, E. (1974). Clin. Chim. Acta 53, I43.

Lloyd, D. R. \& Stringer, D. A. (1978). Proc. XVIth World's Poult. Cong. 1, 55.

Mayes, R. (1982). Br. F. Ind. Med. 39, 183 .

Owen, D. E. \& Doak, S. M. A. (1978). Fd Cosmet. Toxicol. 16,633.

Scrimshaw, N. S. \& Dillon, J. C. (1979). In Single Cell Protein Safety for Animal and Human Feeding, p. 17 I [Garattini, S. et al., editors]. Oxford: Pergamon.

Talbot, C. J. (1978). Proc. Nutr. Soc. 37, 53A.

Vogt, H. Harnisch, S. \& Torges, H. G. (1975). Arch. Geflugelk, 4, 146.

Waslien, C. I., Calloway, D. H. \& Margen, S. (1969). Nature, Lond. $221,84$.

Waterworth, D. G. \& Heath, M. E. (1981). Anim. Feed Sci. Technol. 6, 297.

Whittemore, C. J., Moffat, I. W. \& Taylor, A. G. (1976). F. Sci. Fd Agric. 27, 1163.

Whittemore, C. J., Tullis, J. B. \& Hastie, S. W. (1978). Br. F. Nutr. 39, I93.

Yoshida, M. (1977). Japan. Poult. Sci. 14, 266.

Yoshida, M., Ikumo, H. \& Hoshii, H. (1977). Fapan. Poult. Sci. 14, 284. 